\title{
Comparison of Statistical Methods to Assess Yield Stability in Sweetpotato
}

\author{
J.M. Ngeve ${ }^{1}$ and J.C. Bouwkamp \\ Department of Horticulture, University of Maryland, College Park, MD 20742-5611
}

Additional index words. Ipomoea batutus, genotype $\times$ environment interactions, stability variances

\begin{abstract}
Twenty-seven trials were conducted with 20 sweetpotato [Ipomoea batatas (L.) Lam.] clones in seven locations over 4 years in Cameroon to provide data for the evaluation of statistical methods appropriate for assessing yield stability. Four stability assessment methods were used. Clones 048, TIb 1, 1639, TIS 2498, and TIS 2544 were identified as stable for storage root yield by all four methods. The Eberhart and Russell and Perkins and Jinks methods are statistically related, each detected 9, 8, 9, and 10 clones as stable for total yield, marketable yield, and total and marketable root counts, respectively. Some clones considered stable for yield were found to be unstable for root counts. This result suggests that stability of a complex trait (such as yield) may not depend on stability of component traits. The Shukla method and the Francis and Kannenberg method were considered to be the most effective and useful of those tested. The Shukla method found more clones to be stable; also, the very high-yielding and very low-yielding clones were judged to be unstable. The Francis and Kannenburg method was very convenient, easy to use, and was appropriate for grouping clones of greater and lesser desirability and stability.
\end{abstract}

Plant breeders, in developing improved cultivars, are often confronted with the problem of interpreting genotype $\mathrm{x}$ environment $(\mathrm{G} \times \mathrm{E})$ interactions evidenced by differences in the relative rankings of crop cultivars when compared over a series of environments. The main difficulty for the breeder is in demonstrating the superiority of any cultivar (Eberhart and Russell, 1966). Furthermore, large $\mathrm{G} \times \mathrm{E}$ interactions have been shown to reduce progress from selection (Comstock and Moll, 1963). Eberhart and Russell (1966) stated that while stratification of environments has been used effectively to reduce $\mathrm{G} \times \mathrm{E}$ interactions, it was better to select stable genotypes that interact less with the environments in which they are grown. Statistical methods for determining stability and adaptation of crop cultivars in diverse environments (locations and years) are usually used to assist plant breeders in selecting superior genotypes.

One of the earliest stability methods was developed by Plaisted and Peterson (1959) who estimated a mean variance component for pairwise $\mathrm{G} \times \mathrm{E}$ interaction; the average of the estimated variance components of the $\mathrm{G} \times \mathrm{E}$ interactions for all pairs of genotypes that included a given genotype was the measure of stability for that genotype. Plaisted (1960) developed another variance component for the $\mathrm{G} \times \mathrm{E}$ interaction in which one genotype was deleted from the entire data set and the $G \times$ E interaction variance from this subset was the stability measure for that genotype. Wricke (1962) proposed the concept of ecovalence, which is the contribution of a genotype to the $\mathrm{G} \times \mathrm{E}$ sum of squares; the $\mathrm{G} \times \mathrm{E}$ interaction for a genotype, squared and summed across all environments, is the stability measure for that genotype.

Other methods of assessing stability use regression. Joint regression was first used by Yates and Cochran (1938) who suggested that the environment in which a trial is conducted can be described by the average performance of the genotypes in the particular trial. In 1963, Finlay and Wilkinson used joint regression of mean individual yield on a logarithmic scale to improve lineanarity on the mean yield of all cultivars for each

Received for publication 18 Mar. 1992. Accepted for publication 25 Aug. 1992. The cost of publishing this paper was defrayed in part by the payment of page charges. Under postal regulations, this paper therefore must be hereby marked advertisement solely to indicate this fact.

${ }^{1}$ Present address: Institute of Agronomic Research, Nkolbisson, B.P. 2067, Yaounde, Cameroon. environment. Genotypes with $b$ values not significantly different from 0.0 were judged to be stable, whereas those with significant b values were unstable. Eberhart and Russell (1966) proposed regressions of mean yield on an environmental index calculated as the difference between the environmental mean and the mean of all environments. They also summed the squared deviations from regressions to obtain another estimate of stability. A stable cultivar was one with $a b=1$ and $s_{d}^{2}=0$. Lin and Thompson (1975), using a modification of the regression approach, applied an unweighted pair-grouping cluster analysis to a special dissimilarity index, derived from the test statistic for differences among regressions. Shukla (1972), in defining stability, used stability variance to estimate a component of the $\mathrm{G} \times \mathrm{E}$ interaction corresponding to each genotype. According to his model, a genotype is stable if its stability variance is equal to within environment variance. A significant departure of a genotype's regression coefficient from zero will be indicated by a large stability variance. Francis and Kannenberg (1978) noted the biological and statistical limitations of the Eberhart and Russell (1966) regression method, and the cumbersome nature of the intermediate calculations required by Shukla's (1972) stability variance approach, and proposed the genotype grouping technique as an easier method of measuring stability. Their technique classifies genotypes on the basis of mean yields and coefficients of variation across environments.

Several workers (Ayuk-Takem, 1981; Bacusmo et al., 1988; Crossa, 1988; Funnah and Mak, 1980; Jowett, 1972; Kang and Miller, 1984) have compared methods of stability analyses to study the usefulness of the different procedures for their specific data. Jowett (1972) compared the methods of Eberhart and Russell (1966), Finlay and Wilkinson (1963) and Wricke (1962) in a study of yield stability among sorghum [Sorghum bicolor (L.) Moench] inbred lines in East Africa and found Wricke's method, based on ecovalence, cumbersome and the least informative of the three methods. He concluded that the Eberhart and Russell method, which uses an arithmetic scale, was more explicit than the Finlay and Wilkinson procedure, which uses a logarithmic scale. Funnah and Mak (1980), comparing the Perkins and Jinks (1968), Shukla (1972), and Francis and Kannenberg (1978) procedures in determining genotypic stability in soybeans [Glycine $\max (\mathrm{L}$.) Merr.], found that the three methods differed markedly and recommended the genotype-grouping technique of Francis and Kannenberg as being useful in large test populations. Ayuk- 
Takem, reporting stability analysis on maize (Zea mays L.) cultivars in Cameroon, observed that the Eberhart and Russell (1966) method detected no stable cultivar, whereas the Francis and Kannenberg (1978) procedure found five highland x lowland crosses to be relatively stable. Kang and Miller (1984) evaluated the methods of Plaisted and Peterson (1959), Wricke (1962), and Shukla (1972) in determining yield stability of sugar-cane (Saccharum officinarum L.) cultivars. They found the method of Plaisted and Peterson (1959) cumbersome and, as a result, was impractical when many cultivars were evaluated. Shukla's (1972) method was preferred to Wricke's (1962) in the presence of covariates. Crossa (1988), looking for a stability technique that would identify high-yielding and stable genotypes accurately in international trials, compared a spatial method with a modified regression method to determine yield stability of 27 CIMMYT maize cultivars evaluated in 37 locations. He found that the spatial method was the more useful of the two methods because it was more consistent in identifying high-yielding stable cultivars.

Sweetpotato has been shown to be sensitive to environmental variation. Carpena et al. (1982) detected significant $\mathrm{G} \times \mathrm{E}$ interactions among sweetpotato cultivars in the Philippines. Kannua and Floyd (1988) also reported significant G $\times$ E interactions among sweetpotato cultivars in Papua New Guinea and observed that exotic cultivars showed more to $\mathrm{G} \times \mathrm{E}$ interaction than local, established cultivars. In spite of the presence of large $\mathrm{G} \times \mathrm{E}$ interactions in sweetpotato, most of the stability methods mentioned above have not been studied with this crop. A recent stability assessment on sweetpotato was reported by Bacusmo et al. (1988) who compared four methods: Eberhart and Russell (1966), Shukla (1972), Tai (1979), and Sukarso and Engle (1983). They found the first three methods highly correlated and cultivars described as stable by one method were also considered stable by the other methods. Their study evaluated 14 cultivars over four locations and in 2 years, and they calculated stability parameters using data from total and U.S. \#1 roots.

In Cameroon, sweetpotato is grown from sea level to altitudes as high as $2000 \mathrm{~m}$ and is used mainly for human consumption. Storage root marketable yields and counts are very important yield components. Our study was thus conducted to determine 1) the performance and adaptation of several sweetpotato cultivars in many locations differing in altitudes in a tropical environment and, using data from four economically important sweetpotato traits in the tropics; 2) compare four statistical methods (three regression procedures and one genotype grouping technique) for assessing stability; and 3) to determine whether stability of yield is related to stability of component traits, measured from 20 cultivars, evaluated over seven locations in 4 years.

\section{Materials and Methods}

Twenty sweetpotato cultivars (18 improved and two local controls) were evaluated for 4 years (with extension of 3 years at Ebolowa) over seven locations differing in altitude from 80 $\mathrm{m}$ to $2000 \mathrm{~m}$ above sea level in Cameroon (Table 1). These locations represented the major sweetpotato growing areas of Cameroon.

The experimental areas were first cleared of vegetation, ploughed, harrowed, and ridged with a tractor. The ridge centers were $1 \mathrm{~m}$ apart and $50 \mathrm{~cm}$ high. A plot consisted of 3 rows 10 $\mathrm{m}$ long. Twenty vine tip cuttings $30 \mathrm{~cm}$ long were hand-planted (two-thirds buried) $50 \mathrm{~cm}$ apart in the crests of the ridges in
Table 1. Description of environments in which 20 sweetpotato clones were grown. All locations were repeated over 4 years (1984-87) except for Ebolowa, which only had 3 years of data (1985-87).

\begin{tabular}{|c|c|}
\hline Location & Description of location \\
\hline Nyombe & $\begin{array}{l}\text { Humic volcanic endosols; sandy loam; } \\
\text { pH 5.7; maximum temperature } 32 \mathrm{C} \text {; } \\
2250 \mathrm{~mm} \cdot \mathrm{year}^{-1} \text { rain; forest vege- } \\
\text { tation; } 80 \mathrm{masl}^{\mathrm{z}}\end{array}$ \\
\hline Ekona & $\begin{array}{l}\text { Humic endosols; sandy clay loam; } \mathrm{pH} \\
\text { 4.8; maximum temperature 27C; } 555 \\
\mathrm{~mm} \cdot \text { year }^{-1} \text { rain; forest vegetation } 450 \\
\text { masl }^{\mathrm{z}}\end{array}$ \\
\hline Nkolbisson & $\begin{array}{l}\text { Ferralitic sandy clay loam; ferruginous } \\
\text { hard pan at low depths; pH 5.4; } 545 \\
\mathrm{~mm} \cdot \mathrm{year}^{-1} \text { rain; maximum temper- } \\
\text { ature 28C; forest vegetation; } 750 \\
\text { masl }^{\mathrm{z}}\end{array}$ \\
\hline Bambui Plain & $\begin{array}{l}\text { Humic volcanic ferralitic on basalt; } \\
\text { s a n y loam; pH } 4.9 ; 1845 \\
\text { mm } \text { year }^{-1} \text { rain; maximum temper- } \\
\text { ature } 24 \mathrm{C} \text {, grassland vegetation; } 1330 \\
\text { masl }^{\mathrm{z}}\end{array}$ \\
\hline Bambui Upper Farm & $\begin{array}{l}\text { Humic on basalt; sandy loam; pH } 4.6 \text {; } \\
2149 \mathrm{~mm} \cdot \mathrm{year}^{-1} \text { rain; maximum } \\
\text { temperature } 19 \mathrm{C} \text {, grassland vegeta- } \\
\text { tion; } 2000 \mathrm{masl}^{\mathrm{z}}\end{array}$ \\
\hline Hondole ${ }^{y}$ & $\begin{array}{l}\text { Humic; sandy clay loam; } \mathrm{pH} 4.4 \text {; for- } \\
\text { est vegetation; } 650 \mathrm{masl}^{\mathrm{z}}\end{array}$ \\
\hline Ebolowa & $\begin{array}{l}\text { Humic; sandy clay loam; pH } 3.9 ; 1962 \\
\text { mm.year }{ }^{-1} \text { rain; maximum temper- } \\
\text { ature 29C; forest vegetation; } 650 \\
\text { masl }^{\mathrm{z}}\end{array}$ \\
\hline
\end{tabular}

${ }^{\mathrm{z}}$ masl $=$ meters above sea level

${ }^{\mathrm{y}}$ Weather data not available.

each row. All trials were planted in Apr. 1984-87, and harvested after 4 months. Harvest was later ( $\approx 9$ months) at the highest altitude site (Bambui Upper Farm) to account for slower development of the crop. No fertilizers or plant production measures other than weeding were applied during growth.

Hand harvesting of the middle ridge was used for data collection. Vines were cut and removed, ridges opened up with a hoe, and the storage roots dug out. Roots were then separated into marketable and unmarketable using an established visual grading scheme. Marketable storage roots included all roots with a cross-sectional diameter of at least $4 \mathrm{~cm}$. Thus, data were obtained on total yield (t-ha- $\left.{ }^{\circ}\right)$, marketable yield $\left(\mathrm{t}^{-} \mathrm{ha}^{-1}\right)$, total number of storage roots per square meters, and number of marketable storage roots per square meters. At all sites, a randomized complete-block design with four replications was used.

The results of all the 27 trials were subjected to a combined analysis of variance (ANOVA) to examine $\mathrm{G} \times \mathrm{E}$ effects. Cultivar effects were fixed, while environment effects were considered random. To determine genotypic stability, the following stability parameters were estimated: 1$) \mathrm{b}$ and $\mathrm{s}_{\mathrm{d}}^{2}$ (Eberhart and Russell, 1966); 2) 1 + B (Perkins and Jinks, 1968); 3) $\hat{\sigma}$ and $\hat{\mathbf{s}}^{2}$ (Shukla, 1972); and 4) coefficients of variation for the determination of Groups I-IV (Francis and Kannenberg, 1978).

\section{Results and Discussion}

Combined ANOVA for total yield, marketable yield, total and marketable numbers of storage roots are presented in Table 2. The mean squares for environments, clones, and $\mathrm{G} \times \mathrm{E}$ were 
Table 2. Combined analyses of variance for yield and yield components of 20 sweetpotato clones grown in 27 environments.

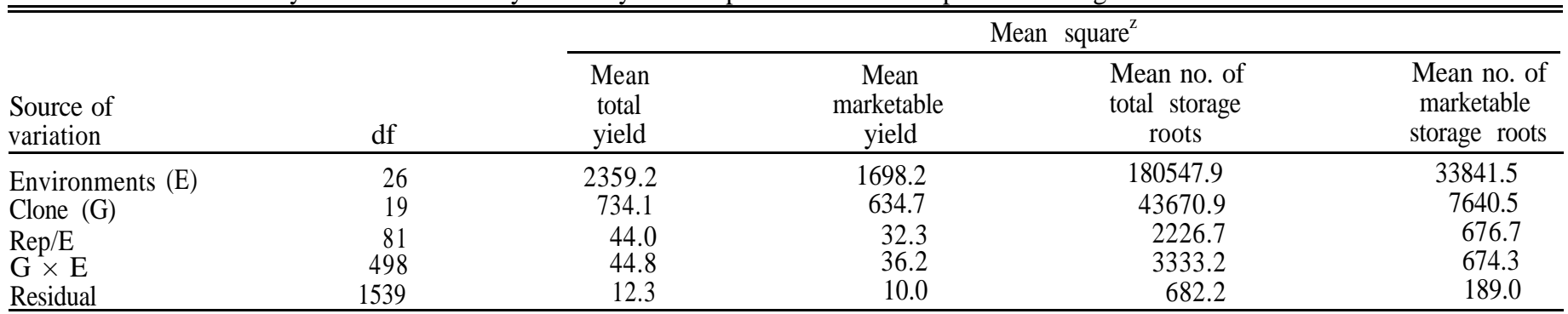

${ }^{\mathrm{z}} \mathrm{F}$ ratios for all sources of variation were significant at $P=0.0001$ for all parameters.

highly significant $(P=0.0001)$ for all variables, indicating that the clones differed in their pattern of response relative to each other in the various environments.

Total yield. Estimates of stability parameters for total storage root yields (Table 3 ) for nine clones had regression coefficients (b) not significantly different from $b+1.0$. Thus, based on $b$ values alone, clones 048, TIS 2544, 1592, TIb 1, TIS 2498, $002,1692,1669$, and 1639 can be considered stable for total storage roots yields. Clone 1611 had a b value significantly $>1.0$, whereas the remaining clones had b values significantly $<1.0$. Regression coefficients have been used to measure genotype response to varying environments. Most of the remaining clones, 076, TIb 2, and the local cultivars, with b values less than unity, consistently performed poorly in all environments. Pritts and Luby (1990) suggested that for many quantitative traits it may not be desirable for genotypes to have low variability and that it should respond positively to improved environmental conditions provided by a grower, rather than exhibit a constant performance. In Cameroon and in most developing countries in the tropics, where research funds are limited and where farmers do not use inputs such as fertilizers on a regular basis to improve environmental conditions, a cultivar once developed should be able to serve many growers in the country. Excess production may not be required because processing is rudimentary. Hence, a desirable cultivar may still be one whose yield is consistent over several locations.

For total yields, five clones had $\mathrm{s}_{\mathrm{d}}^{2}$ values not significantly different from 0 (Table 3 ). Hence, according to $s_{d}^{2}:=0$, clones 076, TIb 1, 1487, 002, 1602, and Njombe could be considered stable. However, Eberhart and Russell (1966) described a desirable genotype as one with a high mean yield, $b=1.0$ and $s_{d}^{2}=0$. Considering this definition, TIb 1 can be considered as the most desirable among the 20 clones. Clone 002, although having a regression coefficient equal to unity and deviation from regression not significantly different from 0 , had a storage root yield below average. Clone 048 yielded well above average $\left(14.8 \mathrm{t} \cdot \mathrm{ha}^{-1}\right)$, had a $\mathrm{b}=1.0$ value, but a $\mathbf{s}_{\mathrm{d}}^{2}$ value significantly higher than 0; as a result, it could be regarded as unstable for total root yield.

The $1+$ B stability parameter proposed by Perkins and Jinks

Table 3. Estimates of six stability parameters for total storage root yield of 20 sweetpotato clones.

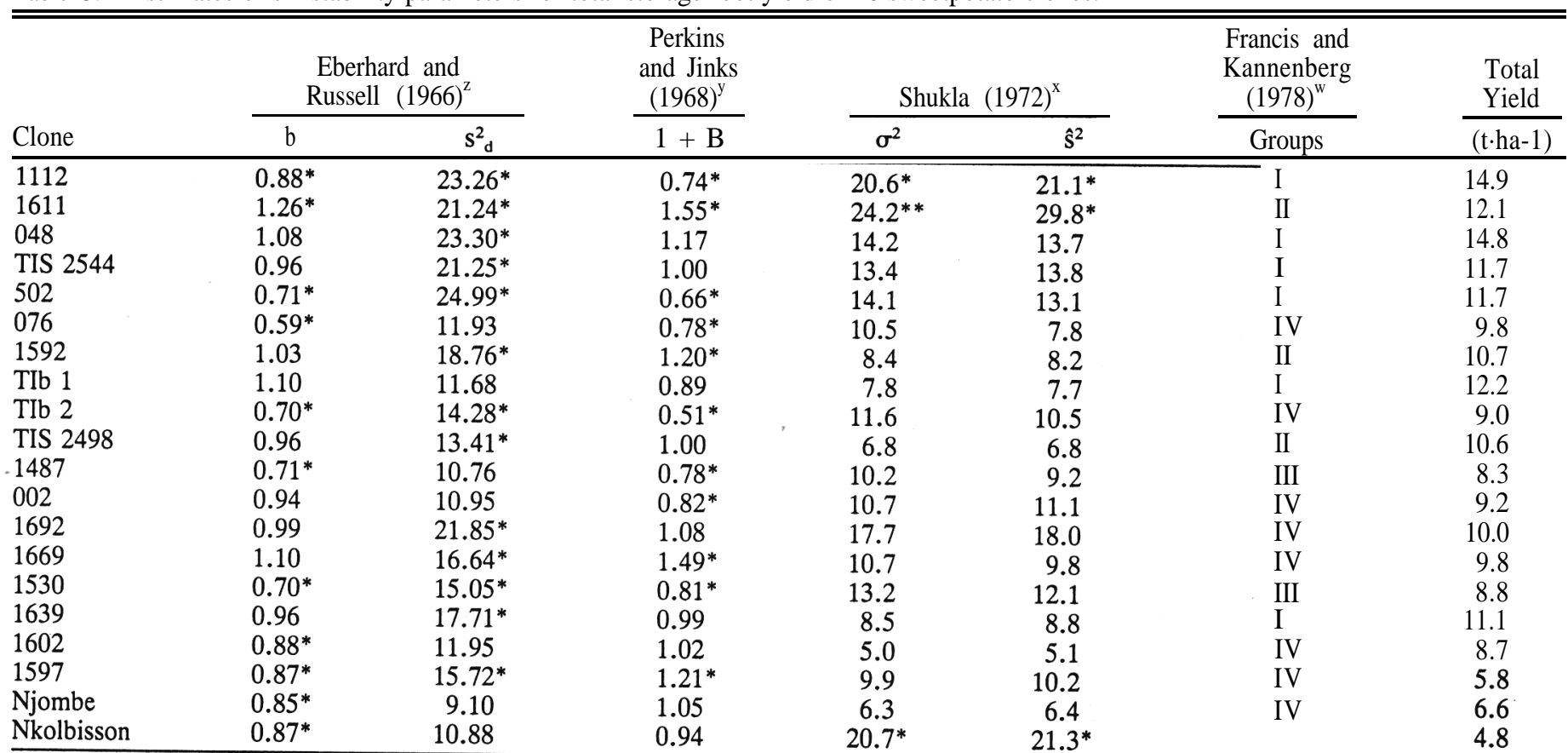

$\mathrm{z}_{* \mathrm{~b}}$ value significantly different from $\mathrm{b}=1.0 ; * \mathrm{~s}^{2}{ }_{\mathrm{d}}>0(P=0.05)$.

$\mathrm{y}_{*} 1+\mathrm{B}$ value significantly different from $1+\mathrm{B}=1.0(P=0.05)$.

x****Significantly unstable at $P=0.05$ and 0.01 , respectively.

${ }^{\mathrm{w}}$ Groups: I high yield, small variation; II high yield, large variation; III low yield, small variation; IV low yield, large variation. 
Table 4. Estimates of six stability parameters for marketable yield of 20 sweetpotato clones.

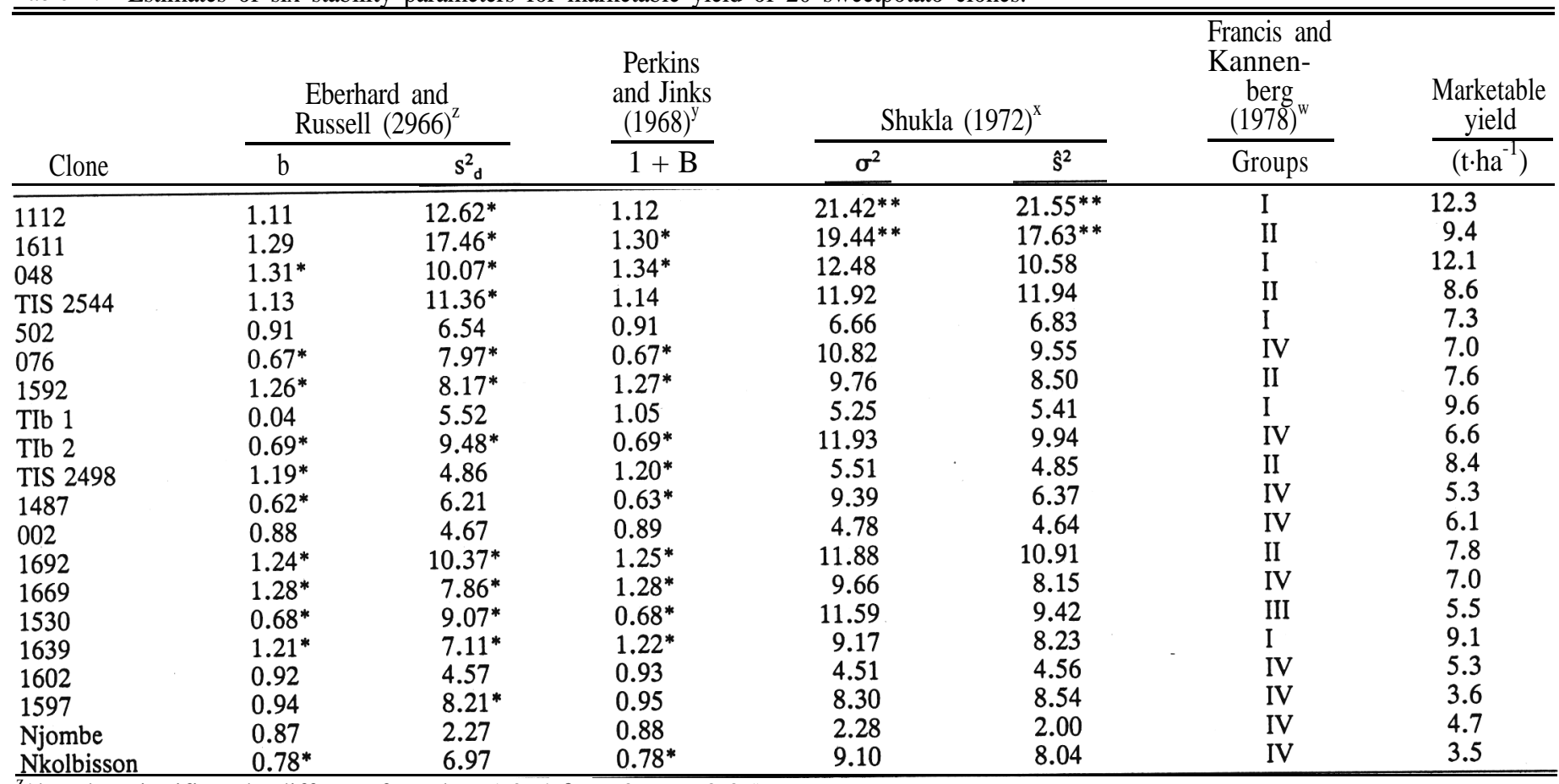

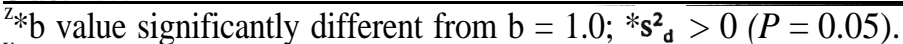

$\mathrm{y}_{*} 1+\mathrm{B}$ value significantly different from $1+\mathrm{B}=1.0(P=0.05)$.

x*,**Significantly unstable at $P=0.05$ and 0.01 , respectively.

${ }^{\text {w} G r o u p s: ~ I ~ h i g h ~ y i e l d, ~ s m a l l ~ v a r i a t i o n ; ~ I I ~ h i g h ~ y i e l d, ~ l a r g e ~ v a r i a t i o n ; ~ I I I ~ l o w ~ y i e l d, ~ s m a l l ~ v a r i a t i o n ; ~ I V ~ l o w ~ y i e l d, ~ l a r g e ~ v a r i a t i o n . ~}$

(1968) detected stable genotypes in a manner similar to that of Eberhart and Russell (1966). For instance, considering total yields (Table 3), as in the Eberhart and Russell (1966) computation, nine clones had $1+\mathrm{B}=1.0$ values and were thus considered stable. Most of the clones considered stable by the Eberhart and Russell (1966) regression coefficient parameter were also related as stable by the Perkins and Jinks (1968) method. This similarity is expected because both methods are regression methods, although in the Perkins and Jinks (1968) method, the observed values are adjusted for location effects before regression is carried out.

Shukla's (1972) stability variance method was more liberal in rating genotypes for stability. His $\hat{\sigma}^{2}$ parameter showed that for total storage root yields, 17 clones were stable; clone 1602 was the most stable, followed by Njombe, TIS 2498, and TIb 1 (Table 3$)$. Clone 1611 was rated as highly unstable $(P=$ 0.01 ), followed by 1112 and Nkolbisson. The model was extended to adjust for the presence of a covariate (the linear effect of the environment) by the calculation of another stability parameter $\left(\hat{\mathbf{s}}^{2}\right)$. Three clones, 1112, 1611, and Nkolbisson, were still found to be unstable. However, 1611, initially identified as unstable at the $P=0.01$ level of confidence was, after adjustment for covariate effects, now found to be unstable with lesser confidence $(P=0.05)$. If a clone, initially judged unstable (from the $\hat{\sigma}^{2}$ computation) is later rated stable (or unstable to a lesser degree), this is an indication that the instability of that genotype was caused by some linear effect of the environment. The environmental covariates could be soil fertility, rainfall distribution, or insolation. Thus, the instability of 1611 might have been brought about by the poor lateritic soils of Nkolbisson, the infertile sandy soils of Hondole, and/or the low temperatures of Bambui Upper Farm.

The last stability method employed was the genotype group- ing technique of Francis and Kannenberg (1978), which groups genotypes on the basis of their mean yields and their coefficients of variation relative to the grand mean and average cv. For total storage root yields, the procedure identified six clones, 1112, 048, TIS 2544, 502, TIb 1, and 1939, as most desirable with higher than average yield and smaller than average cv (Group I). Clones 1611, 1592, and TIS 2498, although yielding above average, were judged to be less stable by this procedure because they had larger than average difficult coefficients of variation (Table 3). Clones 1487 and 1530 were considered undesirable because, even though they had small coefficients of variation, they produced yields below average (Group III). Nine clones (seven improved and two locals) were identified as very undesirable (Group IV) because they yielded below average and had large cv (Table 3).

Marketable yield. For marketable storage root yields (Table 4) eight clones, 1112, TIS 2544, 502, TIb 1, 002, 1602, 1597, and Njombe, had regression coefficients $(\mathrm{b}=1.0)$. Seven clones (1611, 048, 1592, TIS 2498, 1692, 1669, and 1639) had b values $>1.0$, indicating they were adapted to better growing environments, whereas clones 076, TIb 2,1487,1530, Njombe, and Nkolbisson, with regression coefficients significantly $<1.0$, produced poor marketable yields over all environments. Eight clones had $\mathbf{s}_{\mathbf{d}}^{2}=0$ values and were thus considered stable for marketable yield. Clone Njombe $\left(s_{d}^{2}=2.27\right)$ was the most stable, followed by $1602\left(s_{d}^{2}=4.57\right)$ and $002\left(s_{d}^{2}=4.67\right)$. However, considering Eberhart and Russell's (1966) description of desirability, only clone TIb 1 can be considered desirable and stable for marketable yield production because it satisfied all three conditions of above-average yield, $\mathrm{b}=1.0$, and $\mathrm{s}_{\mathrm{d}}^{2}=$ 0 . Clone $502\left(b=1.0\right.$ and $\left.s_{d}^{2}=0\right)$ produced just average marketable yield (7.3 tha-1) and $1602\left(\mathrm{~b}=1 ; \mathrm{s}_{\mathrm{d}}^{2}=0\right)$ had marketable yield below average and were therefore considered 
less desirable although stable (Table 4). For the Perkins and Jinks method, eight clones as in the Eberhart and Russell b parameter had $1+\mathrm{B}$ values $=1.0$ and were thus judged stable. Shukla's (1972) $\hat{\sigma}^{2}$ parameter rated two clones, 1112 and 1611, as highly unstable $(P=0.01)$ for marketable yield. Even after removal of covariate effects, these two clones were still rated as highly unstable (Table 4). Five clones were placed in Group I and nine in Group IV using the Francis and Kennenberg method. Clone TIS 2544, which was described as stable for total yields, was found to be unstable for marketable yields. This difference emphasizes the importance in describing stability of genotypes, indicating which trait was considered.

Total number of roots. With regard to total numbers of storage roots, (Table 5) nine clones had regression coefficients (b) not different from unity and were thus judged to be stable. However, only three clones (1112, TIb 1, and 1639) had s $\mathrm{s}_{\mathrm{d}}^{2}$ values not different from zero.

The same nine clones considered stable for total storage root count by the Eberhart and Russell (1966) method were also the ones rated as stable by the Perkins and Jinks (1968) procedure. Clones 1611,502 , and 1602 were identified as highly unstable $(P=0.01)$ and clones 1692 and Nkolbisson as unstable $(P=$ $0.05)$ by the $\hat{\boldsymbol{\sigma}}^{2}$ parameter by the method of Shukla. When the model was extended for removal of the covariate, the $\hat{\mathbf{s}}^{2}$ parameter identified only clones 502 and 1602 as unstable $(P=0.01)$. Nkolbisson and 1692, initially identified as unstable by the $\hat{\boldsymbol{\sigma}}^{2}$ parameter, were now judged to be stable by $\hat{\mathbf{s}}^{2}$, indicating that their instability was induced by a linear effect of the environment. Seven clones were identified as desirable (Group I) and five as undesirable (Group IV).

Marketable number of roots. For number of marketable storage roots, 10 clones had $\mathrm{b}=1.0$ values, whereas only two clones, TIS 2498 and 002, had $\mathbf{s}_{d}^{2}=0$ values (Table 6). However, according to Eberhart and Russell's (1966) definition of stability, TIS 2498 was the only clone fitting the description of stability based on all three parameters of above-average yield, $\mathrm{b}=1$, and $\mathbf{s}_{\mathrm{d}}^{2}=0$.

The Perkins and Jinks (1968) procedure detected as stable the same 10 clones found to be stable by the Eberhart-Russell (1966) $\mathrm{b}$ parameter. The Shukla parameter, $\hat{\boldsymbol{\sigma}}^{2}$ identified two clones as unstable: 1611 unstable at $P=0.05$ and TIS 2544 unstable at $P=0.01$. However, the $\hat{\mathbf{s}}^{2}$ parameter identified only one clone (TIS 2544) as unstable, this time at $P=0.05$. Four clones $(112,048$, TIS 2498, and 1639) were rated in Group I and six $(076,1487,002,1602,1597$, and Nkolbisson) in Group IV.

The genotype grouping technique of Francis and Kannenberg (1978) gave a different interpretation of stability from the Shukla (1972) procedure. For instance, most of the high-yielding cultivars were considered stable by the Francis and Kannenberg (1978) method, whereas the Shukla (1972) method rated the very high-yielding and very low-yielding cultivars as unstable.

Of the four stability methods studied, Eberhart and Russell's b was found to be equivalent to Perkins and Jinks' 1 + B. For total yield, marketable yield, and total and marketable number of storage roots, Eberhart and Russell's (1966) and Perkins and Jinks (1968) methods each detected as stable $9,8,9$, and 10 clones, respectively. The two methods are similar, although with the Perkins and Jinks (1968) method, the observed values are adjusted for location effects before regression is carried out.

The deviation from the regression $\left(s_{d}^{2}\right)$ parameter of Eberhart and Russell (1966) differed from their b parameter. Except for marketable yield, fewer clones were rated as stable by $\mathbf{s}_{\mathrm{d}}^{2}$. This agrees with the finding of Bacusmo et al. (1988), who also

Table. 5. Estimates of six stability parameters for total number of storage roots produced by 20 sweetpotato clones.

\begin{tabular}{|c|c|c|c|c|c|c|c|}
\hline \multirow[b]{2}{*}{ Clone } & \multicolumn{2}{|c|}{$\begin{array}{c}\text { Eberhard and } \\
\text { Russell (2966) }\end{array}$} & \multirow{2}{*}{$\begin{array}{l}\text { Perkins } \\
\text { and Jinks } \\
\frac{(1968)^{\mathrm{y}}}{1+\mathrm{B}}\end{array}$} & \multicolumn{2}{|c|}{ Shukla $(1972)^{x}$} & \multirow{2}{*}{$\begin{array}{l}\text { Francis and } \\
\text { Kannen- } \\
\text { berg } \\
(1978)^{\mathrm{w}} \\
\text { Groups }\end{array}$} & \multirow{2}{*}{$\begin{array}{l}\text { Total } \\
\text { no. of } \\
\text { storage } \\
\text { roots } \\
\text { per } \mathrm{m}^{2}\end{array}$} \\
\hline & $\mathrm{b}$ & $s_{d}^{2}$ & & $\sigma^{2}$ & $\hat{s}^{2}$ & & \\
\hline 1112 & 1.02 & 231.96 & 0.99 & 204.2 & 217.6 & $\mathrm{I}$ & 8.5 \\
\hline 1611 & $1.50 *$ & $695.97 *$ & $1.45^{*}$ & $1307.0 *$ & 728.0 & II & 8.9 \\
\hline 048 & 1.11 & 581.38 & 1.08 & 606.4 & 601.9 & I & 8.2 \\
\hline TIS 2544 & 1.12 & $686.81 *$ & 1.08 & $2648.3^{*}$ & 717.9 & $\mathrm{I}$ & 9.7 \\
\hline 502 & $1.33^{*}$ & $2271.58 *$ & $1.29 *$ & 565.9 & 530.7 & II & 13.5 \\
\hline 076 & 1.15 & $517.35 *$ & 1.12 & 565.9 & 530.7 & II & 8.1 \\
\hline 1592 & $0.77 *$ & 391.25 & $0.68 *$ & 504.0 & 392.8 & IV & 7.4 \\
\hline TIb 1 & $1.22 *$ & 191.97 & $1.18^{*}$ & 269.8 & 176.5 & I & 8.2 \\
\hline TIb 2 & 0.97 & 404.09* & 0.94 & 417.8 & 431.4 & IV & 7.1 \\
\hline TIS 2498 & $0.64^{*}$ & $393.76^{*}$ & $0.61^{*}$ & 704.7 & 395.5 & III & 6.5 \\
\hline 1487. & 1.14 & $504.55^{*}$ & 1.10 & 542.4 & 517.4 & I & 8.5 \\
\hline 002 & $1.35^{*}$ & $428.09^{*}$ & $1.31^{*}$ & 704.6 & 408.3 & IV & 8.0 \\
\hline 1692 & $0.51^{*}$ & $541.82 *$ & $0.49^{*}$ & 1140.3 & 558.4 & III & 6.0 \\
\hline 1669 & 1.05 & $520.23^{*}$ & 1.02 & 516.7 & 534.6 & II & 2.0 \\
\hline 1530 & 1.11 & $673.40^{*}$ & 1.07 & 712.8 & 716.5 & I & 9.3 \\
\hline 1639 & $0.78^{*}$ & 234.70 & $0.77^{*}$ & 324.8 & 220.6 & III & 6.5 \\
\hline 1602 & 1.16 & $1658.58^{*}$ & 1.12 & $1789.7^{* *}$ & $1797.4^{* *}$ & II & 8.9 \\
\hline 1597 & $0.72^{*}$ & $477.14^{*}$ & $0.70^{*}$ & 661.7 & 487.2 & IV & 5.7 \\
\hline Njombe & $0.74^{* *}$ & $753.35^{*}$ & $0.71^{*}$ & 931.2 & 791.1 & III & 5.5 \\
\hline Nkolbisson & 0.65 & $808.88^{*}$ & $0.62^{*}$ & $1131.4^{*}$ & 853.5 & IV & 3.7 \\
\hline
\end{tabular}

$\mathrm{z}_{*} \mathrm{~b}$ value significantly different from $\mathrm{b}=1.0 ;{ }^{*} \mathrm{~s}_{\mathrm{d}}>0(P=0.05)$.

$\mathrm{y}_{*} 1+\mathrm{B}$ value significantly different from $1+\mathrm{B}=1.0(P=0.05)$.

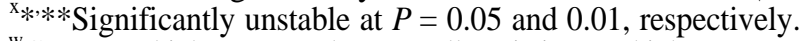

${ }^{\mathrm{w}}$ Groups: I high root numbers, small variation; II high root numbers, large variation; III low root numbers, small variation; IV low root numbers, large variation. 
Table 6. Estimates of six stability parameters for number of marketable storage roots of 20 sweetpotato clones.

\begin{tabular}{|c|c|c|c|c|c|c|c|}
\hline \multirow[b]{2}{*}{ Clone } & \multicolumn{2}{|c|}{$\begin{array}{l}\text { Eberhard and } \\
\text { Russell }(2966)^{\mathrm{z}}\end{array}$} & \multirow{2}{*}{$\begin{array}{l}\text { Perkins } \\
\text { and Jinks } \\
\frac{(1968)^{\mathrm{y}}}{1+\mathrm{B}}\end{array}$} & \multicolumn{2}{|c|}{ Shukla (1972) } & \multirow{2}{*}{$\begin{array}{l}\text { Francis and } \\
\text { Kannen- } \\
\text { berg } \\
\frac{\text { Groups }}{\text { Goups }}\end{array}$} & \multirow{2}{*}{$\begin{array}{l}\text { No. of } \\
\text { marketable } \\
\text { storage } \\
\text { roots } \\
\text { per } \mathrm{m}^{2} \\
\end{array}$} \\
\hline & $\mathrm{b}$ & $s_{d}^{2}$ & & $\sigma^{2}$ & $\hat{\mathrm{s}}^{2}$ & & \\
\hline 1112 & 1.08 & $163.77^{*}$ & 1.09 & 150.1 & 160.4 & $\mathrm{I}$ & 4.5 \\
\hline 1611 & $1.45^{*}$ & $214.85^{*}$ & $1.46^{*}$ & $315.0^{*}$ & 230.5 & II & 4.1 \\
\hline 048 & $1.32^{*}$ & $169.17^{*}$ & $1.33^{*}$ & 214.8 & 177.9 & $\mathrm{I}$ & 4.3 \\
\hline TIS 2544 & $1.24^{*}$ & $294.66^{*}$ & $1.25^{*}$ & $333.6^{* *}$ & $320.4^{*}$ & II & 4.1 \\
\hline 502 & 0.93 & $142.25^{*}$ & 0.94 & 145.7 & 147.8 & II & 4.1 \\
\hline 076 & $0.58^{*}$ & 91.50 & $0.59^{*}$ & 165.2 & 98.2 & IV & 2.9 \\
\hline 1592 & 1.00 & $129.94^{*}$ & 1.01 & 129.0 & 134.0 & III & 2.9 \\
\hline TIb 1 & $1.36^{*}$ & $127.43^{*}$ & $1.38^{*}$ & 188.2 & 134.5 & II & 4.1 \\
\hline TIb 2 & 0.94 & $210.93^{*}$ & 0.96 & 218.9 & 224.2 & II & 3.2 \\
\hline TIS 2498 & 1.10 & 59.95 & 1.09 & 57.3 & 56.8 & I & 3.4 \\
\hline 1487 & $0.73^{*}$ & $127.04^{*}$ & $0.72^{*}$ & 161.3 & 129.6 & IV & 2.8 \\
\hline 002 & 1.08 & 65.11 & 1.09 & 65.1 & 55.9 & IV & 3.0 \\
\hline 1692 & $0.77^{*}$ & $175.04^{*}$ & $0.80^{*}$ & 202.0 & 185.2 & III & 2.7 \\
\hline 1669 & 1.15 & $172.06^{*}$ & 1.17 & 184.3 & $179.6^{\circ}$ & II & 1.3 \\
\hline 1530 & $0.78 *$ & $247.74 *$ & $0.79 *$ & 278.7 & 261.9 & III & 2.9 \\
\hline 1639 & 0.96 & $117.71 *$ & 0.98 & 116.2 & 120.9 & I & 3.3 \\
\hline 1602 & 1.05 & $120.80 *$ & 1.06 & 132.5 & 135.6 & IV & 2.7 \\
\hline 1597 & $0.82 *$ & 85.49 & $0.81 *$ & 96.9 & 87.7 & IV & 1.7 \\
\hline Njombe & 0.93 & 87.57 & 0.95 & 86.7 & 88.3 & III & 2.2 \\
\hline Nkolbisson & $0.74 *$ & 86.09 & $0.76^{*}$ & 171.4 & 147.5 & IV & 1.5 \\
\hline
\end{tabular}

$\mathrm{z}_{*} \mathrm{~b}$ value significantly different from $\mathrm{b}=1.0 ;{ }^{*} \mathrm{~s}_{\mathrm{d}}{ }_{\mathrm{d}}>0(P=0.05)$.

${ }^{\mathrm{y}} 1+\mathrm{B}$ value significantly different from $1+\mathrm{B}=1.0(P=0.05)$.

x****Significantly unstable at $P=0.05$ and 0.01 respectively.

${ }^{\mathrm{w}}$ Groups: I high root numbers, small variation; II high root numbers, large variation; III low root numbers, small variation; IV low root numbers, large variation.

detected fewer stable cultivars of sweetpotato with the $\mathrm{s}_{\mathrm{d}}^{2}$ parameter, for both total and U.S. \#1 root yields.

Shukla's (1972) $\hat{\sigma}^{2}$ and ŝ́stability variance parameters were similar, except that more clones were rated as stable by $\hat{\mathbf{s}}^{2}$ for total and marketable storage root numbers. Also, for total root yields, clone 1611 was rated by $\hat{\boldsymbol{\sigma}}^{2}$ as highly unstable $(P=$ $0.05)$, signifying that the instability of the clone was caused by a linear effect of the environment.

The genotype grouping technique of Francis and Kannenberg (1978) rated six, five, seven, and four clones as stable and desirable for total yield, marketable yield, total root numbers, and marketable root numbers, respectively. Strictly speaking, the Francis and Kannenberg genotype-grouping technique does not separate clones into stable and unstable types. Rather, it classifies them into degrees of desirability. The most desirable clones in Group I are both high yielding and have the lowest cvs (coefficient of variation) possible. The least desirable clones in Group IV are both low yielding and have large cvs. Clones with these two qualities likely will not be selected by the breeder. A disadvantage for the use of $\mathrm{cv}$ is that, if variances of the genotypes are homogeneous and not correlated with the means, a bias is introduced, whereby high means result in low $\mathrm{cv}$ and low means in high cvs. Simple tests to detect homogeneity of variance and correlation of variances and means will aid in the interpretation of the model.

In our study, the Francis and Kannenberg (1978) and Shukla (1972) procedures were the ones found most useful and informative. The genotype grouping technique was the easiest and clearest method. It involves less computation than the Shukla method. It uses two simple and reliable statistics of a cultivar: its mean performance and its coefficient of variation. The technique grouped the cultivars into four classes-cultivars with high mean yields with low cv, such as 1112, 048, 502, and TIb 1 ; those with high mean yields with high cv, such as 1611 ; low yielding with low mean yields with large cv, such as the local cultivars; and 1602, 1597, TIb 2 , and 002 . The simplicity of the procedure makes it versatile in its application. Funnah and Mak (1980) also found it to be very convenient in their work with soybean.

The Shukla method, although requiring cumbersome calculations, identified stable clones and explained the instability of the unstable clones by adjusting for covariate effects. For instance, clone 1611 was rated highly unstable, but after adjusting for a covariate, the clone was still found to be unstable but to a lesser degree. The Shukla procedure was very informative in this study, which agrees with the finding of Bacusmo et al. (1988), who rated the method as the best of the four methods they used. The model also showed that the highest and lowest yielding genotypes are likely to be unstable, a notion that had been inferred by the studies of Tai (1979) and Crossa (1988). Also, Shukla's (1972) method rated more clones unstable for total root counts than for total yields. Some clones that had been judged stable for yield were judged unstable for root counts. This inconsistency in ranking was more noticeable in clones producing the most and fewest root (clones 502 and 1669, respectively). Clone differences for stability for root yields and root counts makes it important, when considering stability, to specify the trait that was measured in the assessment. Such differences also suggests that stability for a component of a complex trait, such as yield, may not be a requirement for stability of the complex trait. Thus, genotypes with unstable component traits by stable yield may have better than average compensatory capabilities.

The methods of Eberhart and Russell (1966), Shukla (1972), 
and Francis and Kannenberg (1978) can all be used to provide reliable parameters for estimating stability and adaptation. The Eberhart and Russell and Perkins and Jinks methods need not be used a the same time because they lead to similar conclusions. The Eberhart and Russell (1966) method requires fewer calculations than the Shukla (1972) method, which may be quite cumbersome, especially when many cultivars are involved. In the absence of high-speed computers, the Francis and Kannenberg (1978) procedure may be the easiest method that can be used to obtain reasonable estimates of genotypic stability and adaptation.

Considering that a stable cultivar is one whose performance relative to the environment is consistent and/or predictable, it follows that those genes that affect the trait in question and their expression, relative to the environment, are similar to an average cultivar. We may presume that an unstable cultivar contains genes that are challenged differently by a different environment. This situation can be visualized if we have a genotype carrying a unique tolerance to a pathogen, occurring occasionally in an environment, and unique susceptibility to a second pathogen also occurring occasionally. Such a cultivar would almost certainly be found unstable, since it is responding to different elements in the environment than the other cultivars. Unstable genotypes are probably unusual but may provide useful germplasm even though they are unsuccessful as cultivars. Stability estimates may be as helpful in identifying potentially useful parent genotypes as in identifying successful cultivars.

Our study suggests that the use of more than one statistical stability procedure may aid in such interpretations.

\section{Literature Cited}

Ayuk-Takem, J.A. 1982. Response of $S_{1}$ varieties and varietal hybrids to altitude and environments in Cameroon. J. Agr. Sci. (Camb.). 98:615-622.

Bacusmo, J.L., W.W. Collins, and A. Jones. 1988. Comparison of methods of determining stability and adaptation of sweet potato. Theor. Applied Genet. 75:492-497.

Carpena, A.L., E.T. Rebancos, P.H. Manguiat, M.M. Zalmeda, G.E. Sajise, and J.L. San Pedro. 1982. Stability of yield performance of some sweet potato cultivars. Philippine Crop Sci. J. 5:30-33.

Comstock, R.E. and R.H. Moll. 1963. Genotype-environment interactions. In.: W.D. Hanson and H.F. Robinson (eds.). Statistical genetics and plant breeding. Natl. Acad. Sci.-Natl. Res. Council Publ. 982:164-196.

Crossa, J. 1988. A comparison of results obtained with two methods for assessing yield stability. Theor. Applied Genet. 75:460-467.

Eberhart, S.A. and W.A. Russell. 1966. Stability parameters for comparing varieties. Crop Sci. 6:36-40.

Finlay, K.W. and G.N. Wilkinson. 1963. The analysis of adaptation in a plant breeding programme. Austral. J. Agr. Res. 14:742-754.

Francis, T.R. and L.W. Kannenberg. 1978. Yield stability studies in short season maize. I. A descriptive method for grouping genotypes. Can. J. Plant Sci. 58:1029-1034.

Funnah, S.M. and C. Mak. 1980. Yield stability studies in soybean. Expt. Agr. 16:357-392.

Jowett, D. 1972. Yield stability parameters for sorghum in East Africa. Crop Sci. 12:314-317.

Kang, M.S. and J.D. Miller. 1984. Genotype $\times$ environment interactions for cane and sugar yield and their implications in sugarcane breeding. Crop. Sci. 24:435-440.

Kannua, M.B. and C.N. Floyd. 1988. Sweet potato genotype x environment interactions in the highlands of Papua New Guinea. Trop. Agr. (Trinidad) 65:9-16.

Lin, C.S. and B. Thompson. 1975. An empirical method of grouping genotypes based on a linear function of genotype environment interaction. Heredity 34:225-263.

Perkins, J.M. and J.L. Jinks. 1968. Environmental and genotype-environmental components of variability. III. Multiple lines and crosses. Heredity 23:339-356.

Plaisted, R.L. 1960. A shorter method for evaluating the ability of selections to yield consistently lower locations. Amer. Potato J. 37:166-172.

Plaisted, R.L. and L.C. Peterson. 1959. A technique for evaluating the ability of selections to yield consistently in different locations or seasons. Amer. Potato J. 36:381-385.

Pritts, M. and J. Luby. 1990. Stability indices for horticultural crops. HortScience 25:740-745.

Shukla, G.K. 1972. Some statistical aspects of partitioning genotypeenvironmental components of variability. Heredity 29:237-245.

Sukarso, G. and L.M. Engle. 1983. A maximum performance model for cultivar evaluation. Philippine Agr. 66:184-190.

Tai, G.C.C. 1979. Analysis of genotype-environment interactions of potato yield. Crop Sci. 19:434-438.

Wricke, G. 1962. Uber eine Methode zur Erfassung der okoligischen Streubreite in Feldversuchen. Z. Pflanzenzucht 47:92-96.

Yates, F. and W.B. Cochran. 1939. The analysis of groups of experiments. J. Agr. Sci. 28:556-580. 